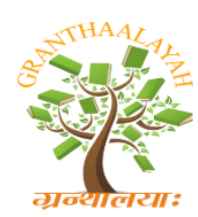

INTERNATIONAL JOURNAL OF RESEARCH GRANTHAALAYAH A knowledge Repository

Social

\title{
IMPACT OF ICT IN DISTANCE EDUCATION AND TEACHER PERCEPTION TOWARDS KNOWLEDGE OF ICT TOOLS
}

\author{
Dr. Rajendra Gupta *1 \\ ${ }^{* 1}$ Assistant Professor, AISECT University, Raisen, India
}

DOI: https://doi.org/10.29121/granthaalayah.v5.i1.2017.1731

\begin{abstract}
The Information and Communication Technology (ICT) can be one of the important tools while teaching at under graduate and post graduate level. It is being popular at education sector because of their different modes of operations. Since, the education includes regular, online, distance and part time education, so there are a number of applications based on ICT are available in the real world. In this paper, the emphasis is given on the use of ICT by teachers and its effects on the teaching methods with their different perspectives. The paper has also focused on the certain important issues related to the effective implementation of ICTs at educational level and provides suggestions for effectively use of ICT at higher education level for distance education.
\end{abstract}

Keywords: ICT; Distance Education; Teachers Knowledge About ICT.

Cite This Article: Dr. Rajendra Gupta. (2017). "IMPACT OF ICT IN DISTANCE EDUCATION AND TEACHER PERCEPTION TOWARDS KNOWLEDGE OF ICT TOOLS.” International Journal of Research - Granthaalayah, 5(1), 163-171. https://doi.org/10.29121/granthaalayah.v5.i1.2017.1731.

\section{Introduction}

The concept of distance education was introduced near about 1960 in India for making the changes in the education system for those who are not directly able to study at outstation. It has opened the door to provide wider opportunities for the students to undertake higher education. The distance education is very helpful for the student and the people who cannot involve in regular courses. The distance education system not only reduced the initial fear of students but also opened various dimensions of correspondences in education field. It has been noticed that around 30 percent students takes admissions in distance education every year in different field. The distance education institution may be the best option for increasing the literacy rate in education. Broadley, T., J. Downie and D. Gibson. (2015) have given the concept of evolving learning paradigms by re-setting the baselines and collection methods of information and communication technology in education statistics. European Commission (2013) has done 
survey of schools in which they have given the idea of ICT in education. Adomi, E.E. and E. Kpangban (2010) explained the application of ICTs in Nigerian secondary schools.

There are various functions performed at higher education with the help of ICT tools. The ICT can be used for enrolment of students in any course of distance education in the University or educational institutes. In the distance education system, the ICT can be used for making better management of records by the preparation of complete database of all the students for various courses. A number of ICT tools are available that can be utilised at higher education level like Computer, LCD, Smart Board, Projector, mobile for communication etc. These systems provide various facilities like Software and Hardware use, Short Message Service (SMS), Interactive display, online tutorials and many more. Mobile phone is one of the major ICT tool and can be used for different purposes. The information like Exam dates can easily be sent to the student through SMS by Institutes concerned. Even more the enrolled students can be provided username and password for using various online services and resources in the form of academic repositories. The instructional material may be uploaded at the Institutional web portal and CDs of lectures can be provided to the students in place of printed paper or hard copy of educational material. Online fees payment is also possible on the portal of concerned Institute. The use of ICT can be helpful to sort out the problem of the delay in declaration of results of different exams by the institutes. The advantages of using ICT tools include saving of lot of paper work and help the environment by making it pollution free. This system can also bring the transparency in the whole system functioning. Nipper S. (1989) has told about third generation distance learning and computer conferencing related issues. Nyirenda, J.E., Indabawa, S.A., \& Avoseh, M.B.M. (1999) has discussed about developing professional adult education programmes in Namibia.

Osin, L. (1998) discussed computers in education in developing countries, why it is and how? Paist, E. H. (1995) has said about serving students with disabilities in distance education programs. Peters, O. (1998) has given the idea of learning and teaching in distance education with the analysis and interpretations from an international perspective. Perraton, H. (2000) has discussed the open and distance learning in developing world. Peters, O. (1989) has talked about the Iceberg has not melted further reflections on the concept of industrialization and Distance Teaching. In the current time, the use of ICT can be helpful for collecting knowledge sources and be an open learning source. The use of technology is one of the major tools that can be utilized only to remove the barriers and challenges present in the existing system. The ICT can provide the opportunity of job training and continuing education for teachers in a convenient and flexible easy manner. Ongoing training can be possible using ICT for the teachers training and students learning. ICT can be applied in their teaching practices as well as for delivery for these trainings. In order to successful implement in the ICT-driven distance education programmes, the teachers must by initially understand and be comfortable with the technologies use. They must be given opportunities and training for acquisition of a new knowledge. This can be possible by promoting computer-training programmes for higher education teachers. Use of ICT in education is very much required for the content designing and delivering. The International Society for Technology in Education (ISTE) has designed and prepared the most comprehensive system of ICT standards for teachers, students and administrators of the educational institute. 
The ICT can be helpful in quality education and distance learning for higher education by implementing it in various phases of education. It can be employed in formal and Non-formal types of education and may be socially useful part of the society. By employing ICT for the teachers training can save a lot of money of the institution and university. Good quality content is one of the major issues in distance learning which can directly affects the standards of education and quality. By the use of ICT effectively, a lot of quality improvement can be done after careful and planned implementation of ICT in education. Shale, D. \& Garrison, D. R. (Eds.) (1990) has given the knowledge of education for distance mode with the discussion of educational issues. Sewart, D. (1993) talked about Student Support Systems in Distance Education. Van der Perre, G. (1999) concept was based on Educational Innovation and Information Technologies (ICT) with Revolution or Evolution. In C. Feyten \& J. Nutta (Eds.), and written about Virtual Instruction with its issues and insights from an international perspective. Von Euler, M and Berg, D. (1998) has said about Electronic Media in Open and Distance Education. Yates, C. (2000) has discussed about Adult Basic Education at a Distance. Yunus, M. (1998) have discussed alleviating Poverty through Technology. Science. Wedemeyer, C.A. (1978) talked about Independent Study. Wills, B. (1993) has discussed on Distance Education with the suggestion of a Practical Guide of distance education. The World Bank (2000) report is published on Higher Education in Developing Countries.

\section{Objectives of the Study}

The aim of this paper is focussed on the following points:

- To study and evaluate the use of ICT at higher education distance learning

- The use of ICT by teachers for distance education

- To overcome the challenges of ICT barriers at higher education level

- To address ICT benefits for Distance Education Institutions

\section{Methods}

\section{i. Research Methodology}

The effective use of technology at different educational organizational systematic functioning is directly associated with the intertwining of technical and social elements (Friedman, 1998; Heracleous \& Barrett, 2001; Kling, 2000; Mulkeen, 2003; Senteni, 2006). On the basis of teacher and student perspective, the survey of factors has been done which affect teachers teaching with the use of technology for distance learning. The aim of this survey is to examine factors that may directly or indirectly impede teachers' efforts to teach with technology higher educational level. The survey study include -

a) Teachers' confidence in ICT use.

b) Teachers' knowledge of Computer Software.

c) Teachers' behaviour towards the use of ICT

d) Use of technology by teachers' for their personal purposes 


\section{ii. Population and Sample}

To analyse the ICT use by teachers at undergraduate level for different educational institute, a questionnaire has been circulated to teachers working at different colleges and institutes in the study area. After collecting the filled questionnaire, the sample of this study included 35 teachers of various discipline. The average age of the teacher participants was around 30 years, with a minimum age of 24 years and maximum age of 58 years which include male and female staff members. On an average, the teacher in the sample had around 6 years of work experience, with a maximum of 25 years of working experience. Out of these samples, 10 teachers were having less than 2 years teaching experience. In the sample, around 70 percent of the teachers were females. In terms of computer usage and experience, around 35 percent had completed professional computer courses related to basic knowledge in this field.

\section{iii. Tools and Technique}

The use of ICT at higher education level analysis requires some basic demographic profile and knowledge of teacher over ICT. So the questionnaire is divided in different sections. The first section included demographic profile of the teachers' age, teaching experience, educational background, computer facility available etc. The Second section is focussing on the Teachers' knowledge of computer software. The third section is based on the teachers' frequency of software use for personal purposes. The fourth section includes teachers' attitudes towards integrating ICT in teaching. The fifth section focuses on teachers' self-confidence in integrating ICT, and the last section includes teachers' frequency of using ICT for instructional purposes.

The second section is having five different choices like "I cannot use it", "I can use it to a small extent", "I can use it satisfactorily", "I can use it well", "I can use it very well". These options are very helpful to measuring the teachers' knowledge of software. In addition to this, the third section uses again five options like "never", "once or twice a semester", "once or twice a month", "once or twice a week", "almost every day". Similarly, the fourth and fifth sections measure the teachers' behaviour with the help of five options like "completely disagree", "disagree", "neither disagree nor agree", "agree", "completely agree". The sixth section, which measure the teachers' frequency of using various computer programs in classroom practices, teachers had need to write how many times in a week they typically use software in teaching.

\section{iv. Procedure of Data Collection and Analysis}

The data is collected by visiting various educational institution time to time and colleges of the study area and by communicating with the teachers of different departments by getting filled up questionnaire. The sample data were collected using a variety of methods, including one-on-one assessments, computerassisted communication system, and by using questionnaires form. The data analysis has been done by some statistical methods which are discussed in the further section of this research study.

\section{Result}

The questionnaire was based on five parts (which are given in Appendix-I to Appendix-V) in which the first part was based on "Teachers' Confidence in using ICT" was composed of seven points that analyse the teachers' confidence in using computer for their teaching and learning 
purposes in the classroom. $33 \%$ teachers were agreed of selection of appropriate software to use in classroom teaching, $32 \%$ teachers were highly agreed to use Power Point software in the classroom while $41 \%$ teachers were highly agreed to use e-mail services to communicate with the students. Around $58 \%$ teachers were told that the computer can be helpful to the students to learn effectively which shows that the ICT can be apply for distance higher education system for their effective functioning.

The second factor was "Teachers' knowledge of Computer Software" included nine point based on the different types of application softwares. This part of the questionnaire shows $22.42 \%$ of the variance in the teacher's perspective. The items included in this section were "I can't use it", "I can use it at small extent", "I can use it satisfactorily", "I can use it well", "I can use it very well". The result shows that around $70 \%$ teachers can use word processing software very well, $25 \%$ teachers are interested in graphics software, 55\% teachers are comfortable in using multimedia tools and very less teachers have chosen the options for programming languages. Around $65 \%$ teachers are comfortable in using websites while teaching and learning. This shows that again the technology use by teachers can give impact to higher education at distance mode.

The third factor which was "Teachers' behaviour towards the use of ICT", measured teachers' behaviour in using the ICT tools for their teaching and learning. This section was composed of five options that explained $15.93 \%$ of the variance of the questionnaire. The options were "Completely Disagree", "Disagree", "Neutral", "Agree", "Completely Agree". After analysing the data collected from various teachers, it is found that teachers are very much comfortable while using the computer for teaching and learning. The result shows around $72.5 \%$ teachers feel comfortable with the computer in teaching. Very less number of teachers have chosen the option of "Computer stresses me out". Around $42 \%$ teachers have selected that "computer is one of the valuable tool of ICT". The last option "Computer cannot be good teaching tool because it create problems" was selected by $8.4 \%$ teachers.

The fourth factor was "Use of technology by teachers' for their personal purposes" that was composed of eight items that explained $11.40 \%$ of the variance. The options included in this section were "Making Presentation", "Playing games", "Graphics Designing", "Preparation of excel graphs and charts", "Internet surfing", Programming purposes", "Multimedia use", "Word processing use", "Using educational materials". The choices were "Never", "Once or Twice", "In a week", "In a month", "Almost every day". After getting the data, it is noticed that the teachers are interested in making presentation in a month. The percentage of this option was $58 \%$. Around $43 \%$ teachers use excel graphs and charts 'in a week' option. The results shows that the teachers are very much interested in using technology which shows that the ICT can be very much effected for the distance education system.

\section{Discussions \& Result}

The results of this study shows that the responses received from various categories of teachers have a reliability coefficient that is adequately higher. In addition, the evidence of the data received is based on a factor analysis. The questionnaire was based on the ICT tool like computer, internet, multimedia, etc. After data collection, it is found that the teachers perception towards the use of ICT tool in teaching and learning. The study can be helpful to check the 
teacher's interest and knowledge in different field of technology. The received data can be used to gain the knowledge of (a) common software applications use by teacher (b) specialized software applications use (c) encouragement by colleagues (d) computer's value (e) technology infrastructure. However, the results of this study also show that the teachers can use ICT effectively for teaching in distance mode.

On the basis of above results and data collection, it is found that if the knowledge of technology and training of the software tool is given to the teacher for teaching purposes, the result would definitely be better.

\section{References}

[1] Broadley, T., J. Downie and D. Gibson. (2015). "Evolving learning paradigms: Re-setting the baselines and collection methods of information and communication technology in education statistics post-2015". Montreal: UNESCO Institute for Statistics.

[2] European Commission (2013). "Survey of Schools: ICT in Education. Benchmarking Access, Use and Attitudes to Technology in Europe's Schools" Belgium: European Commission.

[3] Adomi, E.E. and E. Kpangban (2010). "Application of ICTs in Nigerian Secondary Schools". Retrieved from: http://www.webpages.uidaho.edu/ mbolin/adomi-kpangban.htm

[4] Nipper S. (1989), Third Generation Distance Learning and Computer Conferencing, in MASON R. \& Al., Mindweave: Communications, Computers and Distance Education, Perrgamon Press, Oxford.

[5] Nyirenda, J.E., Indabawa, S.A., \& Avoseh, M.B.M. (1999). Developing Professional Adult Education Programmes in Namibia. University of Namibia: Windhoek

[6] Osin, L. (1998) Computers in Education in Developing Countries: Why and How? Education and Technology Series. 3(1):1-14. Washington D.C. Worldbank.

[7] Paist, E. H. (1995). Serving Students with Disabilities in Distance Education Programs. In The American Journal of Distance Education, 9 (1). 61-70.

[8] Peters, O. (1998). Learning and Teaching in Distance Education: Analysis and Interpretations from an International Perspective. London: Kogan Page.

[9] Perraton, H. (2000). Open and Distance Learning in Developing World. London. Routledge.

[10] Perry, W. (1976). The Open University, Milton Keynes: Open University.

[11] Peters, O. (1989). The Iceberg Has not Melted Further Reflections on the Concept of Industrialization and Distance Teaching. Open Learning, 11 (1), 51-54.

[12] Rogers, E. (1995). Diffusion of Innovations 4th ed. New York. Simon \& Shuster.

[13] Rowntree, D. (1992). Exploring Open and Distance Learning. Kogan Page.

[14] Rumble, G. (1997). The Costs and Economics of Open and Distance Learning. London. Kogan Page

[15] Rumble, G. (2001). Just How Relevant Is E-Education to Global Educational Needs? Open Learning. 16(3): 223-232.

[16] Saints, W. (1999). Tertiary Distance Education and Technology in Sub-Saharan Africa. Washington D. C.: Working Group on Higher Education, Association for the development of Education in Africa, The World Bank.

[17] Shale, D. \& Garrison, D. R. (Eds.) (1990). Education at a Distance: From Issues to Practice. Malabar, FL: Kreiger.

[18] Sewart, D. (1993). Student Support Systems in Distance Education. In open Learning, 8 (30), 312. 
[19] Van der Perre, G. (1999). Educational Innovation and Information Technologies (ICT): Revolution or Evolution. In C. Feyten \& J. Nutta (Eds.), Virtual Instruction: Issues and Insights from an International Perspective. Englewood. Libraries Unlimited.

[20] Von Euler, M and Berg, D. (1998) The Use of Electronic Media in Open and Distance Education. Paris: UNESCO.

[21] Yates, C. (2000) Adult Basic Education at a Distance. Cambridge: International Extension College. Paper prepared for the Knowledge Bank of the Imfundo project. Online: http://www.imfundo.org/Yates/contents.htm. Retrieved 22 March 2002.

[22] Yunus, M. (1998) Alleviating Poverty through Technology. Science. 282(5388):409-410.

[23] Wedemeyer, C.A. 1978.Independent Study. In. Knowles, A.S. (Ed.) The International Encyclopedia of Higher Education. San Francisco: Josey-Bass Publishers.

[24] Wills, B. (1993). Distance Education: A Practical Guide. Englewood Cliffs. NJ. Educational Technology Publications.

[25] World Bank (2000). Higher Education in Developing Countries. Peril and Promise. Washington D.C.: The World Bank.

*Corresponding author.

E-mail address: rajendragupta1@yahoo.com

\section{Appendix}

\section{Appendix 1:}

\section{DEMOGRAPHIC PROFILE OF TEACHER}

\section{Please fill the following information about you :}

Age

Gender

Teaching experience (in year)

Teaching experience in current college

How many years ago were computers introduced in your college?

How many computer are there in your college?

How many computers are there in your lab?

How many computers and LCD are there in classroom?

Do you have computer at home?
1. Female

2. Male

$\overline{-10}$
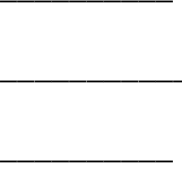
1. Yes
2. No 


\section{Appendix 2:}

\section{Teachers' confidence in ICT use}

Please mark the tick in front of the appropriate option -

\begin{tabular}{|c|c|c|c|c|c|}
\hline & $\begin{array}{l}\text { Completely } \\
\text { Disagree }\end{array}$ & Disagree & Neutral & Agree & $\begin{array}{l}\text { Completely } \\
\text { Agree }\end{array}$ \\
\hline $\begin{array}{l}\text { Selection of appropriate software to use in classroom } \\
\text { teaching }\end{array}$ & & & & & \\
\hline I can use Power Point Software in my class & & & & & \\
\hline $\begin{array}{l}\text { I can design technology for learning activities to the } \\
\text { students }\end{array}$ & & & & & \\
\hline $\begin{array}{l}\text { I can use e-mail services to communicate with the } \\
\text { students }\end{array}$ & & & & & \\
\hline I can teach students for selecting appropriate software & & & & & \\
\hline I can use the internet in learning lessons & & & & & \\
\hline The computer can help students to learn effectively & & & & & \\
\hline
\end{tabular}

\section{Appendix 3:}

\section{Teachers' knowledge of Computer Software}

Please mark the tick in front of the appropriate option -

\begin{tabular}{|l|l|l|l|l|l|}
\hline & $\begin{array}{l}\text { I can not } \\
\text { use it }\end{array}$ & $\begin{array}{l}\text { I can use it at } \\
\text { small extent }\end{array}$ & $\begin{array}{l}\text { I can use it } \\
\text { satisfactorily }\end{array}$ & $\begin{array}{l}\text { I can use } \\
\text { it well }\end{array}$ & $\begin{array}{l}\text { I can use it } \\
\text { very well }\end{array}$ \\
\hline Word Processing Software & & & & & \\
\hline MS Excel & & & & & \\
\hline Graphics Software & & & & & \\
\hline Multimedia Tools & & & & & \\
\hline e-mail & & & & & \\
\hline Websites & & & & & \\
\hline Programming languages & & & & & \\
\hline Presentation Software like Power Point & & & & & \\
\hline Publishing Software & & & & & \\
\hline
\end{tabular}




\section{Appendix 4:}

\section{Teachers' behaviour towards the use of ICT}

Please mark the tick in front of the appropriate option -

\begin{tabular}{|l|l|l|l|l|l|}
\hline & $\begin{array}{l}\text { Completely } \\
\text { Disagree }\end{array}$ & Disagree & Neutral & Agree & $\begin{array}{l}\text { Completely } \\
\text { Agree }\end{array}$ \\
\hline $\begin{array}{l}\text { I feel comfortable that computer can be used as } \\
\text { teaching and learning }\end{array}$ & & & & & \\
\hline Computer stresses me out & & & & & \\
\hline $\begin{array}{l}\text { If something goes wrong, I don't feel } \\
\text { comfortable }\end{array}$ & & & & & \\
\hline Computer is one of the valuable tool of ICT & & & & & \\
\hline Computer can change the way of teaching & & & & & \\
\hline Computer can be used to teach in effective way & & & & & \\
\hline $\begin{array}{l}\text { Computer cannot be good teaching tool because } \\
\text { it create problems }\end{array}$ & & & & & \\
\hline
\end{tabular}

\section{Appendix 5:}

\section{Use of technology by teachers' for their personal purposes}

Please mark the tick in front of the appropriate option -

\begin{tabular}{|l|l|l|l|l|l|}
\hline I use the computer for - & Never & $\begin{array}{l}\text { Once or } \\
\text { Twice }\end{array}$ & $\begin{array}{l}\text { In a } \\
\text { week }\end{array}$ & $\begin{array}{l}\text { In a } \\
\text { month }\end{array}$ & $\begin{array}{l}\text { Almost } \\
\text { every day }\end{array}$ \\
\hline Making presentation & & & & & \\
\hline Playing games & & & & & \\
\hline Graphics Designing & & & & & \\
\hline Preparation of excel graphs and charts & & & & & \\
\hline Internet surfing & & & & & \\
\hline Programming purposes & & & & & \\
\hline Multimedia use & & & & & \\
\hline Word processing use & & & & & \\
\hline Using educational materials & & & & & \\
\hline
\end{tabular}

